\title{
Enhancing Adaptive Capabilities of Hospitalized Child
}

\author{
Kazimierz Kopczyński ${ }^{1, *}$, Marta Gajek², Aneta Michałowska ${ }^{2}$ \\ ${ }^{1}$ Institute of Pedagogy Science, Faculty of Social Science, Jan Kochanowski University in Kielce- branch in Piotrków Trybunalski, Poland \\ ${ }^{2}$ Faculty of Education Science, University of Łódź, Poland
}

Copyright $\bigcirc 2017$ by authors, all rights reserved. Authors agree that this article remains permanently open access under the terms of the Creative Commons Attribution License 4.0 International License

\begin{abstract}
Hospitalization is always a difficult situation for a child as well as for its parents. It is also a new situation, accompanied by fear and negative emotions. Child's adaptation to hospital conditions and reduction of fear are not always taken into consideration properly, as the whole process of hospitalization is concerned. The most significant issues are diagnosis and treatment, most often pharmacological or surgical. Usually, there is also not enough qualified personnel (clinical psychologist, special educator), who could provide necessary support to a child and his or her parents. Not much however, has been written so far regarding the subject of our research, that is why, in our opinion, there is an urgent need of conducting further studies based on theory and developing appropriate model of prevention and psycho-correction, which would take into consideration an individual approach towards the child, depending on its age, family situation, type of disease, the length of hospitalization, as well as child's interests and talents. In our research on children from the age of pre-kindergarten to older schoolchildren, we chose the monographic method to conduct a conversation and an interview (most often with the parents), observation, analysis of the child's works and the gap-test (version for children). The aim of our research was to familiarise with the child's history and its psychic activity, with emphasis on cognitive factors which make the child aware of the whole situation concerning disease, help to estimate losses and benefits, the role of the parents and the child itself. While doing our research, in relation to the examined children, we made psycho-corrective proceedings of enhancing their adaptive capabilities to hospital conditions. One of integrative plays we used, was called Guess the emotions. We also used an exercise called Paint the feelings moreover, forming the attitudes of positive thinking and self-acceptance as well as development of interests were also introduced. Individual approach to ill children considering mentioned above effects, presented in the article have become a part of so called integrated therapy which may turn out to be the most promising and effective form of therapy developed in future.
\end{abstract}

Keywords Hospitalized Child, Adaptation, Disease, Fear, Psychical Activity, Enhancing Adaptive Abilities

\section{Introduction}

\subsection{The Disease as an Event in the Development Process}

One of the most important periods in the human development is childhood. This factor largely determines the course of further development in the next stages of life. Therefore, all difficult situations and problems experienced in childhood, such as disease, can be stored forever and have a significant impact on the mental activity of the child and the formation of its personality. The disease, regardless of the course and prognosis, as a biological disorder, can cause negative changes in child's physical development. Depending on the degree of disease, particularly chronic one, could affect the sphere of social development. As every human being is a psychosomatic unity, there is always an unavoidable impact of the disease on the mental life.

The effects of every disease, even the same one, are sometimes very different for various children. Not only genetic predisposition or anatomy is responsible for this, but above all, the uniqueness of the personality of each child. The disease can change the current development cycle. Life of a sick child and its family is transformed into a completely different set of requirements and restrictions, which they all must face.

According to the psychosocial concept of disease, disease processes can be caused by, among others, incorrect lifestyle, the manner of personal emotional response to the problems, the level of optimism in life. For children, there are also mentioned disorders of emotional development and socialization process resulting from the loss of a loved one, rejection, insecurity and deprivation of love. This disease model highlights not only medical attention, but also for strengthening the psychological resistance of the patient and his or her family and is based on understanding concerning the life history and social interactions of the patient[1,2]. Every child's disease transforms his or her concept of himself or herself, which has been built earlier. The changes associated with the disease, occurring in appearance, 
particularly for girls, may be of great importance. The image of physical development is also impaired - obesity, short stature, lack of a sense of strength and efficiency, what plays a significant role among boys. Physical appearance has an impact on social functioning of children and young people as well as on their life plans [3]. Regardless of gender, every child affected by illness may feel isolated, worse and sometimes, as a result of abovementioned, less loved. This happens due to the vivid children's imagination. Often their conjectures have any foundations, but the fact that they are not like other children, makes them feel as if they were different.

The disease changes the current life of every child, often it is difficult to foresee how it will impact on its further development. Therefore it should be endeavoured to prevent the consequences of experiencing a disease that can leave significant mark on entire life. Considerable guarantor of the child's return to health is the harmonious coexistence of family members, who mutually share positive feelings and support. Psychological and pedagogical assistance should therefore always include the ill child and its family.

\subsection{The Perception and Understanding of the Disease by the Child}

As Pilecka [4] highlights, the scope of the content of such concepts as 'disease' and 'health' and the nature of assimilated information depends on the children's stage of their cognitive development which systematically changes with age. There is, however, a question whether contact with the disease, which takes place especially among children with chronic diseases, leads to more advanced understanding of disease-related concepts, or perhaps, as a consequence of experiencing disease, impairs the cognitive development. Overview of studies discussed by Thompson, Jr. \& Gustafson [5], indicates non-uniform results. The children experiencing hospitalization present less, equally, and more sophisticated concepts of the disease compared with those who were not hospitalized. Results of studies do not confirm the expectations that tensions associated with the necessity of coping with a chronic disease would cause a lower level of cognitive development in terms of the health and disease concept.

On the basis of conducted research, Banasiak [3], presents the factors affecting the perception of the disease by the child, such as the duration of the disease, the patient's current health status as well as treatment procedure requires pharmacotherapy and frequent medical monitoring. Many children believe that through their illness, they have a lower efficiency than their peers and therefore are worse than them. Likewise, the dependence of sick children from others does not influence their positive perception and understanding of the disease.

The children aged from 2 to 7 , are not able to distinguish the cause from the effect, for instance, in their interpretation the cough is already a disease, not the symptom. Often, children in this age group consider the disease as a punishment for their improper behaviour and associate it with external events. When children are about 4 , they ask their parents great number of questions, among others, in order to satisfy their cognitive needs. Just then, the parents should take advantage of this time and hold an honest conversation with the child about the disease - its symptoms, examinations and treatment. Considering children between 7 and 12 years old, their way of thinking becomes more concrete and logical. They are already capable to distinguish the causes and effects of the disease. They realize that with the help of medical care their condition may be improved. It is important to remember, however, that up to the age of 12 , the children, however, have limited ability to analyse and anticipate. They do not realize the consequences of illness, relevant to their future life [6].

Children's conceptions concerning hospital, medical personnel and surgeries, as well as disease, have also proved to be related to their level of cognitive development. Previous experiences of hospitalization improved the level of the hospital concept among pupils of the second year of primary school, but not for children in preschool age [5].

The perception of the disease by the child as well as its understanding depends largely on its parents or other adults with whom the child resides and from who receives information. Conducting proper conversation with the child about his or her illness plays a key role in adaptation to the illness itself.

Obuchowska \& Krawczyński [1], indicate that to the cognitive factors that help realize the disease situation to the child, include: awareness of the disease, knowledge about the disease, evaluation of losses and benefits and the assessment of the parents' role and their own role. It is important to pay a special attention to a very significant, for adaptation processes, cognitive factor, which is the assessment of the role of parents and the role of the child itself in the course of the disease. There are three main assessments of the parents' role in the process of disease. Firstly, the ill child can consider the parents as helpless and depend only on the instructions from people from the outside. The child may also overestimate the parents' possibilities, which in many cases are helpless. However, this is not detrimental to the child, because due to this fact, the child willingly follows their advice, executes the commands and has a sense of security. The third type of assessment can be considering parents responsible for any disease, which is being justified by the negligence or transfer of the disease - in the case of hereditary diseases.

In the fight against the disease a significant factor is not only the parents' role, but also the role of the child itself. The child should be aware that a lot depends on him or her. Important thing is its attitude to the disease, willingness to improve health, implementation the recommendations of doctors, change in eating habits, and emotional state. To improve or reinforce these values, the child should be allowed to decide on matters related to his or her illness, 
which simultaneously supports his or her self-esteem.

Intervention influences aimed at support adaptation should tend to shape the child's sense of internal control. The importance of locus of control in itself, the so-called inside-steering, in increasing adaptability, was indicated by Thompson, Jr. \& Gustafson [5] and Sikorska [7]. In view of their studies, the most effective measures are those that enhance the ability of self-reinforcing

\subsection{The Influence of Hospitalization on Course of the Disease and Child's Psychic Activity}

Child's disease, in particular chronic one, is frequently associated with long hospital stays. The ill child has disturbed physical and mental activity. His or her mood deteriorates, and is forced to stay in the hospital where everything is different - new rooms, people, sounds, smells. This is a new situation for the child, which may occur difficult to accept.

The inevitable contact with medical personnel, instruments and apparatus can trigger a sense of danger. The immobilization of the child in connection with its illness is unpleasant, especially as at this age there is an increased need for physical activity. Limited mobility arouses in negative emotions, such as annoyance, sense of injustice despondency. Immobilization of the child is also connected with lower self-reliance and dependency on others. In the case of chronic diseases, when this situation continues for a long time, the child can become little resourceful and powerless. The whole process of becoming independent and shaping of motivation is endangered. This may result in future difficulties in independent decision-making and in lack of persistence [8]. Children's hospital stay causes different reactions. Highly important role plays factors such as age, level of development, personality and social environment from which the child comes from. Despite the differences determining a different reaction, there are certain common standards for specific stages of development. Child in the period of $1-4$ years of age is extremely attached to its mother, and when she is absent, he or she expresses dissatisfaction. During the first days of hospital stay, the child's protests, despair and frustration are often encountered. This is caused by the fear of separation from mother. School-aged child also fears of separation, but not only with the mother, but also with extended family and friends [9]. The consequences of hospitalization may not always be visible immediately after leaving the hospital by the child. They can appear in a distant time when they are not expected. Traumatic experiences can exceed child's mental toughness and cause that he or she becomes hostile, unreliable, not resistant to pain, distrustful in relation to adults. Long hospital stay and limited contact with family can also lead to the disorder of emotional development [1]. Disease and hospitalization are unavoidably associated with stress. According to Selye [10] stress is the nonspecific response of the body to any demand. Stressful situation initially stimulates human activity aimed at improving its relationship with the environment and regain balance. However, if it lasts too long and is too burdensome for a man, it violates an internal balance and trigger negative emotional reactions. Changes occur as a result of stress is dis-adaptive, reducing an individual's ability to adapt and self-regulation $[2,8]$. According to some authors, exposure to risk factors may enhance processes related to mental resistance. Rutter [11] calls this phenomenon steeling effect. Fergus \& Zimmerman [12], in suggested inoculation model indicate that the risk factor may have a function of protective agent, the immunizing further difficult situations. In the context of stressors affecting the child, which are illness and hospital stays, the observation made by Olsson, Bond, Burns, Vella-Brodrick \& Sawyer [13], that caution should be exercised in making such generalizations, seems reasonable. They believe that there is nothing quenching in experiencing the adversity by a young man who, in the course of a short development, has not yet developed enough to protect himself or herself. Equally, Thompson, Jr \& Gustafson [5] indicate that children from the age of about 6 months to 4 years of age are the most vulnerable to transitional and long-term effects of hospitalization.

\subsection{Psychological and Social Support for Affected Child}

Supporting the adaptation possibilities of a sick child will be presented more broadly in the discussion concerning the results of our research. Here, we would like to draw attention to the three spheres of influence. The first is the formation and development of interests. The role of interest in the teaching process is generally known. Considerably less however, is recognized the psycho-correction function that which can be performed by interests. Gurycka [14], in her model definition of interests, indicates that the integral factor of interest is the experience of feelings connected with the acquisition and possession of knowledge. Interests therefore, significantly affect the emotional development of the child, as well as deepen social bond and make the child more flexible on its influence. Here, we are dealing with the process of socialization interests. Interests stimulate action and underline its value, as well as contribute significantly to create the internal locus of control, so vital for the adaptation processes [15, 16]. Rogers [17], in his model of nondirective treatment, draws attention to the use of positive areas of psychic activity of human in correcting the disordered spheres. Interests perfectly fit into the positive field of human activities.

Another, very important support area of adaptation possibilities of the child to the disease and hospitalization is associated with the impact of family, especially parents. Fenella, Adamson \& Hull [9] suggest that parents should encourage the child to confidences of its doubts and feelings associated with the disease. It depends largely on parents whether their children stay in hospital will be a positive and strengthening experience for them. When preparing the child 
for the hospital stay, the parents should remember that the child should take a favourite toy, or a photo of the family, which will increase the sense of security. The high level of family cohesion, as noted Pilecka [4], reduces depressive symptoms in stressful life situations. Frequent and systematic staying with a sick child at home and in the hospital is often the most effective mean of preventing the consequences of hospitalization.

The third sphere of influence, which is worth to be mentioned is social support. There are support groups for parents of affected children, e.g. an international network of support groups Candelighters Childhood Cancer Foundation. Candelighters name derives from the belief that, 'it is better to light a candle than curse the darkness'.

In accordance with the definition of health which is included in WHO constitution: "Health is a state of complete physical, mental, and social well-being and not merely the absence of disease or infirmity" as accepted model of medicine. In socio-psychological model of health it is considered as an ability to perform life activities and social roles. In the following article we distinguish three dimensions of the state: disease, illness and sickness.

\section{Method}

\subsection{Examined Persons}

The research included children hospitalized in the period from April to July 2016 in Kutnowski Self-Governmental Hospital as well as in District Hospital of St. Faustina Kowalska in Łęczyca. Hospitalization time was different according to child's disease. The population surveyed consisted of 20 children, aged 6 - 17 years old.

The aim of the study was to investigate the psychic activity of hospitalized child and conditioning concerning this activity, in particular the impact of the disease and hospitalization on orientation in itself and in the environment of respondents as well as on their affective activity.

The study had also the psycho-corrective goal: enhancing the adaptation abilities of the child to the hospital environment, improving dysfunctional forms of activity, reducing of anxiety.

\subsection{Tools}

In the research, monographic method by S. Gerstmann [18] was applied, the method allows for a deeper understanding of an examined person and his or her history of life in an individual and qualitative manner. Implementing the study by this method, we used: observation, conversation, interview, analysis of documents and products of action. Supplementally, the gap-test were used: of J. Kostrzewski (for younger children) and of J.M. Sacks \& L. Sidney (for older children), as well as the Inventory of Interests of A. Frydrychowicz, J. Jaworski, A. Matuszewski \& T.
Woynarowska (for older children).

In accordance with the principle of the primacy of the problem rather than the method, most appropriate, according to the purpose of our research was, in our opinion, the monographic method, useful both for diagnostic and psycho-corrective purposes [19-22]. Particularly useful in this method are research techniques such as conversation and interview. They have been characterized in detail by $\mathrm{S}$. Gerstmann [18], who indicates that the conversation is conducted with the examined person and the interview with other people, and about the person concerned. In the case of our research, interview was conducted mostly with parents and siblings of the child. The gap-test was applied according to the recommendations of $\mathrm{P}$. Gerstmann [23], as an introduction to the conversation or as its supplementation.

In the psycho-correction, understood for the $\mathrm{P}$. Gerstmann[23] as a psychological impact aimed at improving the psychological aspects of unsatisfactory and problematic position in life, referring to all its elements primarily related to mental activity - we used various methods of influence, according to the age of the child and medical and psychological diagnosis. In particular, the conversation and the interview should be indicated, which are both the methods (techniques) as well diagnostic and corrective. The interview, particularly with the mother of the child, provides valuable diagnostic information, but also helps to shape the orientation in itself and in the maternal surrounding and direct her further action in relation to the child and thus, indirectly influence the mental activity of the child. In the psycho-corrective, integration play was also used: Guess the emotions and an exercise Paint the feelings, bibliotherapy, fairy tales therapy, gelotology, eco-therapy, development of interests, forming positive thinking, help in organizing time, short - and long-term planning.

\subsection{The Study Procedure}

The research was conducted in the hospital and in the family home of the children, as well as - in terms of eco-therapy - among natural surroundings. The first contact with the examined child took place usually in the hospital, sometimes even before hospitalization. Subsequent meetings - after approval by the caregivers - were held at its family home, or in the case of longer hospitalization, in the hospital. It should be noted in fact, that the process of strengthening adaptive capabilities should start even before the hospitalization of the child and should be continued after he or she left the hospital. The stress associated with stay in the hospital remains commonly in the child long after the hospitalization and in the case of chronic diseases, the child will probably need to stay in the hospital again.

With every child, we had at least a few diagnostic and corrective meetings, using the aforementioned methods. Some meetings were attended by all members of the immediate family, along with the child. Separate meetings were devoted to interviewing the child's parents. The course 
of the study was differentiated depending on the child's health situation, the length of his or her hospitalization and the possibility of further meetings in the family home.

Psychological and pedagogical model of diagnosis and correction is fundamentally different from the medical model, in which diagnosis precedes treatment. According to S. Gerstmann \& P. Gerstmann [19], in clinical psychology, diagnosis and correction are parallel (permanently), and the same diagnosis, discovering what is positive in the examined person through realizing him or her this fact as well as appreciation, becomes an element of correction. Therefore, in our opinion, enhancing the adaptive capabilities of hospitalized child took already place during the first meeting.

\section{Results}

Our studies, conducted with the use of above mentioned methods and techniques were of a qualitative nature and their presentation, at the general level, would be very difficult, or even impossible. Problematic life situation of each child was different due to the nature of the disease, a different family situation and a unique history of life. Every affected child was for us a unrepeatable unit, available for research only when using the monographic method. Psycho-correction focused primarily on enhancing the adaptive abilities to the disease and hospitalization, preceded individually and differently in relation to every child. The common procedures may be indicated, such as integration activities, Paint the feelings exercise, gelotology - laughter therapy, which is used in relation to each affected child while strengthening adaptation [24, 25], eco-therapy, developing of interests and creating positive thinking. However, the specific use of these forms of child's activation, supporting its adaptation and self-enhancing have individual and different character. General intervention strategies aimed at enhancing adaptation by preventing or minimizing disturbances in the normal processes of child's development, reflecting in school work and relationships with peers and parents, but as assumptions, they were similar, they have been adapted to the individual development of each child and the specifics of his or her social interaction.

We would like to characterize more specifically one of the examined children, with particular emphasis on psycho-correction, while the broader context of this monographic study will be reviewed in the Discussion section.

The person examined was a ten-year-old boy named Gregory, hospitalized because of the removal of the third almond. He stayed in the hospital for three days. However, there is a risk of his further hospitalization for another reason. In Gregory's brain, there was found a damage in its frontal part, possibly due to a head injury he had experienced in early childhood. The boy is under the care of a neurologist. Enhancing the adaptability to the disease and the hospital environment is therefore particularly justified.
Gregory has three sisters and all the siblings, from seven years have lived with mother. Father is abusing alcohol and they have no contact with him. The boy is interested in computer games and football. During his stay in the hospital, Gregory was scared, he did not know at first what to expect, how the procedure runs and how long it lasts. Mother also had little information on the planned procedure and expressed many concerns. As a single parent with four children she has a lot of responsibilities and burdens, and she also requires mental support. In order to effective enhancing the adaptability of Gregory, particularly in the longer term, the assistance should be also provided for mother.

Using the method of mirror obtained mother's permission to experiencing different emotions, e.g. fear, and acceptance them as something natural and always present during lifetime. The realization that emotions are not bad, we just need to learn the proper methods of dealing with them, allowed the mother of Gregory, their acceptance, which resulted in the recovery of peace and relaxation. The perception of emotions by his mother and their acceptance also influenced the feeling of being accepted by the child. In the further psycho-correction directed the mother toward conversations with the boy, and in particular to telling him about her emotions, looking at her son's needs from his perspective, not judging but reflecting the state of the child, for example. 'I think something make you angry'. Properly conducted conversations with Gregory influenced his growth of sense of security and self-esteem, he felt noticed and important. The mother was also recommended to make daily summaries with the exposing what positive happened, active leisure time, e.g. walking or cycling, bibliotherapy, doing something pleasant and exclusively for themselves, listening to quiet, appropriately selected music. Mother realized that giving some time to herself is not an improper thing, but rather recommended. She noticed that when devoting time to relax, she has more patience and she is calmer, which has a positive impact on the entire family.

An important element in identifying and naming emotions by children is reading them therapeutic fairy tales, for example 'When Kan-No-Mushi wakes up'. The result of such bibliotherapy was the realization by Gregory that emotions are nothing wrong and we have an impact on their expression. In relation to the boy, the method of the mirror was also applied. The mother, who is not ashamed of her emotions yet, gave her child the permission to show them as well. The integration play Guess the emotions was also used. We show the child printed pictures with the facial expressions of children, reflecting different emotions. Then, the child draws a picture and guesses what feels the child on the picture, and then we ask: "Why do you think this child is, for example, sad?" At the end we ask the child to compose a story with emotion shown in the picture. As the effect of such play, Gregory realized that people have emotions, depending on the situation in which they are and that we can recognize them through facial expressions.

Another method of psycho-correction, allowing calming 
negative emotions and strengthening the self-control was an exercise Paint the feelings described by Portmann [26]. The child paints on paper with felt tip pens or pencils, the feelings that accompany him or her when loses the temper: anger, fear, fury, helplessness, etc. The child explains his or her picture in relation to their own. The next stage of the exercise is an attempt to change feelings painted earlier, into more positive - even by adding colours and shapes, for example transformation an 'anger' in the positive feeling that is 'joy'. During performing this exercise by the child, we have the opportunity to observe if he or she has difficulties in painting the feelings, and in particular, whether it is easy to change its negative feelings into positive. Subsequent attempts to perform the task allow the child to realize that emotions which cannot be coped with - in Gregory's case it was anger can be changed to something positive, for example satisfaction. At the same time, this exercise shows the child that everyone has an impact on emotional response, what is very important in the context of the formation of self-control, which plays such an important role in strengthening adaptation to illness and hospitalization.

A significant, although underappreciated role in aforementioned adaptation, plays eco-therapy. It encourages the formation of sensitivity, responsibility and unity with the surrounding world. Contact with nature excellently influences cognitive and affective activity, and also makes us feel relaxed and less stressed. We helped Gregory and his mother to organize bicycle trips into the forest. Admiring the cultural landscape, on the way to the forest and stay in there caused the he felt someone important, part of the surrounding world, his self-assessment and self-esteem increased.

An important corrective role plays also a help aimed to the child in the organization of time. In relation to Gregory, particularly significant was limitation of time spending in the front of computer, physical activity, e.g. football, cycling, walking, involvement in domestic duties, helping mother, but simultaneously doing something enjoyable for himself and finally a summary of the day with exposing what was positive. The time organization introduced stabilization to boy's live and increased his sense of security, whereas the responsibilities taken by himself gave the rhythm of his activity and increased sense of meaning in life. Positive summary of the day, in which were included at least some nice values and goals to strive for, is an important step in shaping a sense of internal control, which - as discussed previously - has a significant role in adaptation and coping in difficult circumstances.

Below we present, in a table, methods, performed corrective activities and results in reference to the whole research population.

\begin{tabular}{|c|c|c|}
\hline Methods & Corrective activities & Results \\
\hline $\begin{array}{l}\text { Monographic } \\
\text { Observation } \\
\text { Talks } \\
\text { Discussions } \\
\text { Interviews } \\
\text { Analysis of the } \\
\text { child's works }\end{array}$ & $\begin{array}{c}\text { Psycho-correction } \\
\text { Formation and development of interests } \\
\text { Short-and long-term planning } \\
\text { Positive summary of the day } \\
\text { Eco-therapy } \\
\text { Bibliotherapy, } \\
\text { Fairy tales therapy } \\
\text { Integration activities }\end{array}$ & $\begin{array}{l}\text { Adaptation to a new situation } \\
\text { Increase of the sense of security } \\
\text { Calm of negative emotions } \\
\text { Strengthening of the self-control } \\
\text { Bolstering of the confidence } \\
\text { Social support } \\
\text { Appreciation of positive sides of hospitalization } \\
\text { (f.e. 10-year-old Oliwka listed the following positives: you may watch TV, } \\
\text { make a recovery, be in friendly environment, atmosphere, kind nurses, } \\
\text { comfortable bed) }\end{array}$ \\
\hline
\end{tabular}




\section{Discussion}

Enhancing the adaptive capabilities to the disease and hospitalization in the above-described examined child was individualized and adapted to the specifics of his problematic life circumstances. Methods of enhancing this possibilities which were used in relation to Gregory, were applied - with various modifications - also in relation to the other examined children. Heterogeneity of the population of the research, both in terms of age, as well as medical and psychological diagnosis causes that psycho-correction was different for each child, accents were spread in a different way in relation to specific methods and depending on the achieved correction results, chosen methods were more exposed. Despite these differences, targeting our research and conducted psycho-correction, as it was presented on the example of the examined boy, is justified in relation to other hospitalized children which need strengthening of adaptive capabilities. Significant role has the conversation with the examined child and the interview with his or her caregivers. Psycho-correction should usually cover not only the child but also his caregivers and sometimes other family members, for example siblings. Shaping and developing interests is also essential, it enhances the realm of child's success and therefore it underlines its value. The corrective role of the interests was mentioned in the theoretical part. Eco-therapy creates also unique possibilities for correction and enhancing adaptation. Nowadays, we are dealing with so-called nature deficit syndrome [27]. Eco-therapy aims to compensate this deficit as well as environmental education promotes comprehensive development of the child and the formation of its aesthetic sensitivity and cognitive [28]. For older children, we used the educational values of the cultural landscape. The child described perceived landscape and it appeared that the same landscape described by others was significantly different. Simultaneously, the child can see its uniqueness and the fact that is an integral part of nature, and that nature in a unique way, reflects in its mind. Consequently, self-esteem and the sense of internal control strengthen, what translates directly into adaptive processes [29]. In our interactions we were guided primarily by nondirective therapy model, focused on searching for positive spheres of mental activity of the child and use those positives in the correction of child's activity areas which are disrupted. The keynote, which guided us, is already mentioned maxim saying, 'it is better to light a candle rather than curse the darkness'. We were able to bring out this light in each of the affected children we were dealing with, and we hope that research, presented in this article, as well as its results will be a contribution to further research effort into this field.

In order to increase adaptive abilities of the hospitalized child we underline the necessity of comprehensive model of diagnosis and therapy. Current research have rarely presented this model of approach and the defined methods we have used, corrections and results, have made in our opinion, original contribution in the research progress referring to the hospitalized child as well as the chronically ill or in difficult life situation resulting from different conditions.

\section{Conclusions}

In the face of increasing hazards of civilization and environment for children health, developing psychological persistence of a child, enhancing its adaptation abilities to the disease and hospitalization acquires special significance.

In our opinion very crucial, although unappreciated role plays here psychological talk with a child, interview with its minders, developing its interests, ecotherapy, shaping aesthetic and cognitive sensitivity, bolster its confidence and self-control.

Individual approach to ill children considering mentioned above effects, presented in the article have become a part of so called integrated therapy which may turn out to be the most promising and effective form of therapy developed in future.

\section{Acknowledgements}

We would like to thank the organizers of the $3^{\text {rd }}$ International Interdisciplinary Conference of Health and Psychological Resistance which took place on $23^{\text {rd }}$ and $24^{\text {th }}$ of September 2016 in the Institute of Applied Psychology at Jagiellonian University in Cracow, for inspiration and opportunity to present own researches.

We would also like to thank the management of self-government hospital in Kutno and the St. Faustyna Kowalska county Hospital in Łęczyca for opportunity to conduct the research.

\section{REFERENCES}

[1] I. Obuchowska, M.Krawczyński. Chore dziecko. Nasza Księgarnia, Warszawa, 1991.

[2] A. Maciarz. Dziecko przewlekle chore. Opieka i wsparcie, Wydawnictwo Akademickie Żak, Warszawa, 2006.

[3] B. Banasiak. Spostrzeganie choroby przez dzieci $z$ zaburzeniami rytmu serca i przez dzieci z wadami serca. Doniesienie tymczasowe. In H. Skłodowski (Ed.), Medycyna psychosomatyczna i psychologia chorego somatycznie wobec zagrożenia i wyzwań cywilizacyjnych współczesnego świata (pp. 69-75), Wydawnictwo Uniwersytetu Łódzkiego, Łódź, 1996.

[4] W. Pilecka. Przewlekła choroba somatyczna w życiu i rozwoju dziecka. Problemy psychologiczne, Wydawnictwo Uniwersytetu Jagiellońskiego, Kraków, 2002.

[5] R. J., Jr Thompson, K. E.Gustafson. Adaptation to chronic childhood illness, American Psychological Association, 
Washington, 1996.

[6] K.Wnęk-Joniec, L. Pławecka-Stolarska, N. Lipowska. Poradnik dla rodziców i personelu, Wydawnictwo Narodowego Funduszu Zdrowia, Warszawa, 2014.

[7] I. Sikorska. Odporność psychiczna w okresie dzieciństwa, Wydawnictwo Uniwersytetu Jagiellońskiego, Kraków, 2016.

[8] A.Maciarz. Psychoemocjonalne i wychowawcze problemy dzieci przewlekle chorych, Oficyna Wydawnicza IMPULS, Kraków, 2001

[9] E. Fenella, E., S. J., Adamson, D. Hull. Pielęgnowanie chorych dzieci, Państwowy Zakład Wydawnictw Lekarskich, Warszawa, 1990.

[10] H. Seyle. (1977). Stres okiełznany, Państwowy Instytut Wydawniczy, Warszawa, 1977.

[11] M. Rutter. Implications of resilience concepts for scientific understanding, Annals New York Academy of Science, 1094, 1-12. 2006.

[12] S. Fergus, M. A. Zimmerman. Adolescent resilience: A framework for resilience. In S. M. Southwick, B. T. Litz, D. Charney, M. J. Friedman (Eds.), Resilience and mental health: Challenges across the lifespan (pp. 1-10), Cambridge University Press, Cambridge, 2005.

[13] C. A., Olsson, L. Bond, J. M. Burns, D. A. Vella-Brodrick, S. M. Sawyer. Adolescent resilience: A concept analysis, Journal of Adolescence, 26, 1-11, 2003

[14] A. Gurycka. Rozwój i kształtowanie zainteresowań, Wydawnictwa Szkolne i Pedagogiczne, Warszawa 1989.

[15] K. Kopczyński. Zainteresowania i system wartości u nieletnich zagrożonych samobójstwem, Polskie Towarzystwo Higieny Psychicznej, Warszawa, 1994.

[16] K. Kopczyński, A. Sobczak. Potrzeby rozwijania zainteresowań. In W. Dykcik, C. Kosakowski, J. Kuczyńska-Kwapisz (Eds.), Pedagogika specjalna szansą na realizację potrzeb osób $\mathrm{z}$ odchyleniami od normy (pp. 319-325), Wydawnictwo Naukowe Polskiego Towarzystwa Pedagogicznego, Oddział w Poznaniu, Olsztyn - Poznań Warszawa, 2002.
[17] C. R. Rogers. Terapia nastawiana na klienta. Grupy spotkaniowe, THESAURUS-PRESS, Wrocław, 1991.

[18] S. Gerstmann. Rozmowa i wywiad w psychologii, Państwowe Wydawnictwo Naukowe, Warszawa, 1985.

[19] S.Gerstmann, P. Gerstmann. Podstawy psychologii klinicznej, Wydawnictwo Uniwersytetu Łódzkiego, Łódź, 1982.

[20] S. Gerstmann. Podstawy psychologii konkretnej, Państwowe Wydawnictwo Naukowe, Warszawa, 1987.

[21] K. Kopczyński. Monografia psychologiczna jako metoda o kluczowym znaczeniu w empirycznej psychologii człowieka. In J. Such, M. Szcześniak (Eds.), Osobliwości przedmiotowo-metodologiczne w nauce (pp. 201-218), Wydawnictwo Fundacji Humaniora, Poznań, 1996.

[22] K. Kopczyński. Badania monograficzne w pedagogice. In J. Pańczyk (Ed.), Forum Pedagogów Specjalnych XXI wieku, tom II (pp. 52-63), Wydawnictwo Uniwersytetu Łódzkiego, Łódź, 2002.

[23] P. Gerstmann. Główne zagadnienia psychologii klinicznej. In S. Gerstmann, P. Gerstmann, Podstawy psychologii klinicznej (pp. 116-232), Wydawnictwo Uniwersytetu Łódzkiego, Łódź, 1982.

[24] A. J. Chapman. Społeczne aspekty śmiechu dziecięcego na tle komizmu, Przegląd Psychologiczny, XXII (1), 89-124, 1979.

[25] K. Kopczyński. Gelotologia - terapia śmiechem. In J. Pańczyk (Ed.), Forum Pedagogów Specjalnych XXI wieku, tom III (pp. 129-136), Wydawnictwo Uniwersytetu Łódzkiego, Łódź, 2002 .

[26] R. Portmann. Gry i zabawy przeciwko agresji, Wydawnictwo Jedność, Kielce, 1999.

[27] R. Louv. Ostatnie dziecko lasu, Grupa Wydawnicza Relacja, Warszawa, 2014.

[28] K. Kopczyński. Duchowe, społeczne i terapeutyczne walory wychowania proekologicznego, Kultura i Edukacja, 3 (77), 28-38, 2010.

[29] K. Kopczyński. Edukacyjne walory krajobrazu kulturowego, Problemy Ekologii Krajobrazu, XXII, 7-17, 2009. 